\title{
VI Międzynarodowa Konferencja pt. „Miejsce Innego we współczesnych naukach o wychowaniu. Inny w przestrzeni społecznej", Poznań (Obrzycko) 8-9.04.2013 r.
}

Odmienność, niejednakowość, nietypowość, odrębność, anormalność, oryginalność, różność, wyjątkowość, indywidualność... to tylko kilka określeń, które odnaleźć można w Stowniku języka polskiego pod pojęciem „inność".

Czym tak naprawdę jest owa inność? Kim jest Inny? Kto ustanawia społeczne podziały na "my-oni” i czy ma do tego prawo? Czy istnieją szanse na zmianę obecnej sytuacji? Na te i wiele innych pytań starano się uzyskać odpowiedź podczas VI Międzynarodowej Konferencji pt. „Miejsce Innego we współczesnych naukach o wychowaniu. Inny w przestrzeni społecznej", która odbyła się w dniach 8-9 kwietnia 2013 r. w Obrzycku. Dom Pracy Twórczej pod swym dachem zjednał najwybitniejszych przedstawicieli dwóch płaszczyzn - teorii oraz praktyki. Tegoroczne rozważania oscylowały, tradycyjnie już, wokół Innego. Tym razem szczególny nacisk położono na Jego miejsce w przestrzeni społecznej.

O tym, iż bardzo łatwo zaszufladkować człowieka jako „innego", nie trzeba przekonywać. Jednak znalezienie dla Niego miejsca, podjęcie wysiłku zniesienia społecznych podziałów, ciągle jeszcze stanowi nie lada wyzwanie. Tego zadania podjęli się wybitni polscy i zagraniczni przedstawiciele nauki z zakresu pedagogiki specjalnej, pedagogiki, psychologii, socjologii, filozofii i innych pokrewnych dziedzin z następujących uczelni wyższych: 
Chrześcijańska Akademia Teologiczna w Warszawie, Uniwersytet Gdański, Uniwersytet Warszawski, Uniwersytet Szczeciński, Dolnośląska Szkoła Wyższa, Uniwersytet Komeńskiego w Bratysławie, Uniwersytet Śląski, Uniwersytet Warmińsko-Mazurski w Olsztynie, Politechnika Łódzka, Uniwersytet Zielonogórski, Uniwersytet Pedagogiczny im. KEN w Krakowie, Uniwersytet Jagielloński, Toruńska Szkoła Wyższa, Uniwersytet Rzeszowski, Wyższa Szkoła Pedagogiczna w Łodzi, Uniwersytet im. Marii Curie-Skłodowskiej w Lublinie, Uniwersytet Wrocławski, Uniwersytet Jana Kochanowskiego w Kielcach, Uniwersytet Mikołaja Kopernika w Toruniu, Wyższa Szkoła Edukacji Zdrowotnej i Nauk Społecznych w Łodzi, PWSZ w Gorzowie Wielkopolskim, Uniwersytet kard. Stefana Wyszyńskiego w Warszawie, Wałbrzyska Wyższa Szkoła Zarządzania i Przedsiębiorczości, Wyższa Szkoła Edukacji Integracyjnej i Interkulturowej w Poznaniu, Univerzita Tomáše Bati ve Zlíně, Wyższa Szkoła Nauk Społecznych Pedagogium w Warszawie, MBA Dubnický technologický inštitút v Dubnici and Váhom, Masarykova Univerzita v Brně, Akademia Pedagogiki Specjalnej w Warszawie, Uniwersytet im. Adama Mickiewicza w Poznaniu, Zespół Kolegów Nauczycielskich w Suwałkach.

A także wspaniali przedstawiciele praktyki: Stowarzyszenie MONAR Ośrodek Leczenia, Terapii i Rehabilitacji Uzależnień w Łodzi, Specjalny Ośrodek Szkolno-Wychowawczy nr 13 we Wrocławiu, Poradnia Psychologiczno-Pedagogiczna nr 7 w Gdańsku, Specjalistyczna Poradnia Psychologiczno-Pedagogiczna Doradztwa Zawodowego i dla Dzieci z Wadami Rozwojowymi w Łodzi, Specjalny Ośrodek Szkolno-Wychowawczy nr 6 dla Słabowidzących i Niewidomych w Łodzi, SP ZOZ nr 1 w Rzeszowie, Przedszkole Sióstr Miłosierdzia św. Wincentego a Paulo w Gnieźnie, Areszt Śledczy w Lublinie.

Podczas Konferencji goście mogli obejrzeć wystawę prac fotograficzno-rysunkowych Państwa Matyldy i Macieja Pachowicz, zatytułowaną: „Przysłowiowe portrety", w której uczestniczyły dzieci z Ośrodka Edukacyjno-Rehabilitacyjno-Wychowawczego w Ustroniu. Konferencji towarzyszyła również promocja książki pt. Niepowtarzalni, powstałej w ośrodku. Zawarto $\mathrm{w}$ niej bajki i prace plastyczne uczniów, a także historie opowiedziane przez rodziców oraz terapeutów związanych z ośrodkiem.

Konferencja objęta była patronatem Komitetu Nauk Pedagogicznych Polskiej Akademii Nauk.

Komitet Naukowy konferencji tworzyli: prof. zw. dr hab. Zbyszko Melosik (UAM Poznań), prof. zw. dr hab. Bogusław Śliwerski (APS Warsza- 
wa), prof. zw. dr hab. Władysław Dykcik (UAM Poznań), prof. zw. dr hab. Iwona Chrzanowska (UAM Poznań), prof. zw. dr hab. Amadeusz Krause (UG Gdańsk), doc. PhDr. Albin Skoviera (PhD Uniwersytet Komeński, Bratysława), doc. PhDr. Jaroslav Balvin (CSc. Vniverzita Tomase Bati ve Zline) oraz doc. PhDr. Jarmila Novotna (PhD. Univerzita v Brne).

Natomiast nad organizacją i przebiegiem konferencji czuwał Komitet Organizacyjny Konferencji, w skład którego wchodziły: dr hab. Beata Jachimczak, dr Katarzyna Pawelczak oraz dr Aneta Wojciechowska.

Przewodnicząca Komitetu Naukowego Konferencji, Pełnomocnik Dziekana WSE UAM ds. Specjalnych Potrzeb Edukacyjnych prof. zw. dr hab. Iwona Chrzanowska powitała uczestników konferencji, a Dziekan WSE UAM prof. zw. dr hab. Zbyszko Melosik wygłosił przemówienie otwierające dwudniowe obrady. Zaakcentował w nim rolę, jaką odgrywają tego rodzaju spotkania $\mathrm{w}$ rozwoju nauki. Ukazał także najnowsze osiągnięcia $\mathrm{w}$ dziedzinie pedagogiki, również te mające miejsce na Wydziale Studiów Edukacyjnych Uniwersytetu im. Adama Mickiewicza w Poznaniu.

Po uroczystym otwarciu rozpoczęła się pierwsza sesja plenarna, której przewodniczyła dr hab. prof. DSW Małgorzata Sekułowicz. Znakomici przedstawiciele nauk pedagogicznych, w zaprezentowanych referatach, poruszyli jedne z najbardziej palących wątków w dyskusji pedagogicznej:

Prof. zw. dr hab. Bogusław Śliwerski („Polska oświata jako czynnik destrukcji polskiej demokracji") dokonał analizy zagadnień związanych z wartościami demokratycznymi, ukazując jednocześnie, mający obecnie miejsce, kryzys.

Prof. zw. dr hab. Amadeusz Krause („W cieniu fałszywego paradygmatu - konsekwencje hermeneutycznej niewspółmierności") swoje wystąpienie skupił wokół aktualnych problemów łączących się z uprawianiem nauki akademickiej. Prelegent zaprezentował osobiste przemyślenia na temat sposobu budowania wiedzy naukowej. Według prof. A. Krause mamy do czynienia z homogenizacją treści i tematów opracowań, wiedza nie jest rozszerzana, lecz powtarzana na różne sposoby, co ma niekorzystny wpływ zarówno na rozwój polskich nauk humanistycznych, jak i całego społeczeństwa (w tym studentów pedagogiki i nauk pokrewnych, a także samych naukowców). Wystąpienie to wzbudziło wśród słuchaczy duże poruszenie, a dyskusje na ten temat trwały jeszcze w kuluarach.

Wydźwięk referatu zaprezentowanego przez dr hab. prof. UAM Agnieszkę Cybal-Michalską („Świat karier bez granic - o kulturze życzliwej Inności") był bardzo optymistyczny. Prelegentka postawiła tezę, iż 
w dzisiejszym świecie każdy człowiek ma możliwość odnalezienia odpowiedniego dla siebie miejsca, w którym może się rozwijać i realizować. Dzięki temu ma szansę poszerzania tkwiących w nim samym zasobów, które jednocześnie przysłużą się wzbogaceniu nie tylko jego samego, ale także ogółu społeczeństwa.

Nad możliwościami, zagrożeniami oraz konsekwencjami płynącymi z czynnego uczestnictwa młodzieży w świecie Internetu zastanawiał się dr hab. Jacek Pyżalski („Funkcjonowanie młodzieży online - inaczej czy tak samo?").

Prof. zw. dr hab. Maria Szyszkowska („Kształtowanie światopoglądu jako wyraz autentyzmu Innego") w swoich rozważaniach, osadzonych w kontekście kwestii światopoglądowych i humanistycznych, nawiązała do ogólnie przyjętych wartości. Wyraźnie podkreśliła przy tym znaczenie odrębności każdej jednostki i jej indywidualnego spojrzenia na świat.

Dr hab. prof. US Teresa Żółkowska w wystąpieniu pt: „Inny, dyskurs, emancypacja, puste znaczące" odwołała się do jednych z najważniejszych obecnie problemów w naukach o Inności - podejmowanych dysputach, zagadnieniach związanych z integracją, a także z postępującą emancypacją Innego. Prelegentka akcentowała, iż za pojęciami i definicjami kryje się człowiek, a podejmowane dyskusje i rozważania powinny pociągać za sobą konkretne działania na rzecz osób z niepełnosprawnością oraz ich środowiska.

Kolejny prelegent dr hab. prof. UAM Andrzej Twardowski w referacie pt: „Rola wizyt domowych w procesie wczesnego wspomagania rozwoju dzieci z niepełnosprawnościami" zaproponował nowe rozwiązania $\mathrm{w}$ zakresie wspierania rodzin dzieci z niepełnosprawnością. Odniósł się do wartości oddziaływań terapeutycznych odbywających się na terenie rodzinnego domu dziecka.

Druga sesja plenarna, prowadzona przez dr hab. prof. UAM Agnieszkę Cybal-Michalską oraz dr. hab. Jacka Pyżalskiego, obejmowała dwa obszary zagadnień. Zakres tematyczny prezentowanych referatów dotyczył rodzin dzieci z niepełnosprawnością, zarówno w Polsce - dr hab. prof. DSW Małgorzata Sekułowicz („Rodzice dzieci z niepełnosprawnością. Pomiędzy wypaleniem a prężnością") i dr hab. prof. UWM Agnieszka Żyta („Rola dziadków we wspieraniu rodzin dzieci z niepełnosprawnością"), jak i za granicą - Doc. PhDr. Albin Škoviera PhD („Náhradná starostlivost' - od eklúzie k inklúzii"), który przedstawił sytuację rodzin zastępczych i adopcyjnych na Słowacji. Natomiast drugi obszar zagadnień dotyczył dylematów związanych ze szkolnictwem - dr hab. prof. US Zenon Gajdzica („Inny 
czy powszechny podręcznik dla ucznia z lekką niepełnosprawnością intelektualną w klasie ogólnodostępnej?").

Wystąpienie dr hab. Urszuli Bartnikowskiej stanowiło podsumowanie II sesji plenarnej. Miało ono na celu ukazanie wyzwań stojących przed współczesną pedagogiką specjalną. Prelegentka skupiła się na możliwościach oraz ograniczeniach płynących z łączenia humanizmu z modnym obecnie biologizmem. Ukazała, iż z jednej strony biologizm dodaje dziedzinom humanistycznym „naukowego charakteru”, z drugiej jednak należy nieustannie pamiętać o tym, iż w centrum wszelkich rozważań teoretycznych oraz działań praktycznych stać powinien człowiek.

Obrady zakończyły się dyskusją, w której padło wiele cennych uwag i spostrzeżeń na temat kondycji dzisiejszego szkolnictwa specjalnego.

Popołudniowe debaty prowadzone były w trzech równoległych sekcjach. Pierwszej przewodniczył dr hab. Jacek Pyżalski. Jako punkt odniesienia postawiono miejsce Innego w przestrzeni edukacyjnych wyzwań.

$\mathrm{Na}$ temat przygotowania niepełnosprawnych i pełnosprawnych uczniów do współpracy z sobą referat wygłosił dr Jarosław Bąbka. Prelegent ujął owe zadanie, stojące przed współczesną edukacją, w kategorii wyzwania, które choć trudne, jest możliwe do zrealizowania.

Mgr Štefánia Ferková („,Kyberšikana - možnosti prevencie a intervencie v základných školách”), mgr Dorota Smetanova („Inakost’ komunikácie riziká komunikácie v kyberpriestore") oraz dr Katarzyna Waszyńska („W (nie)rzeczywistej relacji z innymi, czyli miłość i seks w cyberprzestrzeni") w swoich referatach odniosły się do społecznej przestrzeni, szczególnie bliskiej współczesnemu człowiekowi, tzw. cyberprzestrzeni. Przedstawiły bilans strat i zysków płynących $\mathrm{z}$ funkcjonowania ludzi w wirtualnej rzeczywistości.

O przewodniczenie sekcji II poproszona została dr hab. prof. UZ Zdzisława Janiszewska-Nieścioruk. Przemyślenia 12 prelegentów uczestniczących w obradach dotyczyły miejsca Innego w przestrzeni szkolnej. W trakcie spotkania wygłoszono inspirujące referaty, zaprezentowano badania, teoretyczne uzgodnienia, a także poruszono wiele aktualnych, zarówno w teorii, jak i w praktyce, problemów związanych między innymi z:

- integracją (dr Jolanta Lipińska-Lokś „Miejsce Innego w przestrzeni społecznej szkoły we wspomnieniach absolwentów klas integracyjnych"),

- adaptacją oraz wykluczeniem w społeczności klasowej (dr Renata Michalak „Przestrzeń klasy szkolnej miejscem wykluczenia uczniów. Problemy adaptacyjne czwartoklasistów"), 
- chorobą przewlekłą (dr Barbara Olszewska "Czynniki chroniące i czynniki ryzyka związane z chorobą przewlekłą młodzieży wybranych łódzkich szkół gimnazjalnych"),

- wadą słuchu (dr Małgorzata Zaborniak-Sobczak "Samoocena młodzieży z wadą słuchu i jej znaczenie w kształtowaniu się poczucia odpowiedzialności"),

- zaburzeniami ze spektrum autyzmu (dr Aneta Wojciechowska „Znaczenie treningu umiejętności społecznych $\mathrm{w}$ terapii dzieci i młodzieży z zaburzeniami ze spektrum autyzmu"),

- ADHD (dr Dagna Czerwonka „Uczeń z ADHD jako inny w szkole”),

- wybitnymi zdolnościami (mgr Monika Gołubiew-Konieczna, mgr Monika Sztolpa „Uczeń zdolny jako uczeń o specjalnych potrzebach edukacyjnych w polskiej szkole - próba oceny").

Zaprezentowano również próby rozwiązań analizowanych problemów.

Sekcja III odbyła się pod przewodnictwem dr Jolanty Rzeźnickiej-Krupy. Znakomici naukowcy wspólnie zastanawiali się nad Innością w dorosłości.

Dr Dorota Prysak („Inny student uniwersytetu w przestrzeni życia społecznego - doświadczenie jako kategoria nabywania potencjału") omówiła projekty realizowane przez US na terenie województwa dolnośląskiego, takie jak: "Osoba z niepełnosprawnością intelektualną moim sąsiadem”, „Projekt OWCA”, "Adopcja dziecka z niepełnosprawnością". Referentka przedstawiła możliwości wcielenia zasad normalizacji w życie, zwracając jednocześnie uwagę na zasoby tkwiące w społeczeństwie.

Dr hab. Beata Cytowska $w$ prezentowanym przez siebie referacie („Osoba z niepełnosprawnością intelektualną $\mathrm{w}$ zakładzie pracy - z doświadczeń trenera pracy") omówiła badania empiryczne wskazujące na istotność roli trenera związanej z przygotowaniem człowieka z niepełnosprawnością intelektualną do pracy.

Natomiast dr Anna Prokopiak („Inna dorosłość osób z autyzmem i innymi całościowymi zaburzeniami rozwoju") ukazała obraz dorosłości osób z zaburzeniami ze spektrum autyzmu oraz społeczne czynniki wpływające na kształtowanie tego okresu życia.

Sekcję podsumowała niezwykle ciekawa i bardzo wartościowa dyskusja. Prelegenci wraz ze słuchaczami podali w wątpliwość słuszność jednoznacznego określenia dorosłości, debatowali nad jej definicją i wyznacznikami. Zastanawiano się także nad tym, czym jest życiowe spełnienie oraz czy jest ono możliwe do osiągnięcia. Konkluzję dyskusji stanowiły słowa 
prof. zw. dr hab. Marii Szyszkowskiej: „niespełnienie jest stymulacją do rozwoju", będące jednocześnie tematem zadanym do osobistej refleksji.

Drugi dzień obrad rozpoczęły równoległe spotkania w trzech sekcjach.

W IV sekcji, pod czujnym okiem dr hab. Beaty Cytowskiej, przyglądano się tożsamości Innego, którą analizowano pod kilkoma kątami:

Dr Jacek Bylica („,Kwestia romska w Macedonii. Raport z badań pilotażowych”), dr Beata Orłowska („Łemkowie jako ci inni w środowisku społecznym") oraz mgr Beata Pietkiewicz-Pereek („Czy da się zbudować inny świat dzieciom ulicy w Indiach?") przedstawili „Inność” jako odmienność kulturową.

"Inność", rozumianą z kolei jako specyficzna cecha przypisywana jednostce, dostrzec można było w wystąpieniach: dr Anny Gulczyńskiej (,(Nie)zupełnie normalny. Osoby z zaburzeniami psychicznymi w perspektywie społecznej"), dr Jolanty Rzeźnickiej-Krupy i dr Doroty Krzemieniewskiej („Postrzeganie i ekspresja inności w perspektywie doświadczeń egzystencjalnych”), dr Jolanty Baran („Czyja to przestrzeń? Dzieci z uszkodzonym słuchem w przestrzeni społecznej - z perspektywy ich matek"), a także mgr Moniki Karwackiej i dr Katarzyny Pawelczak („(De)stereotypizacja? Wizerunek osoby z niepełnosprawnością w podręcznikach szkolnych").

Odmienności obecnej w literaturze i sztuce doszukały się dr Monika Humeniuk-Walczak („Osobliwości, dziwactwa, potworności - obrazy Inności w kulturze popularnej na przykładzie twórczości Nicka Cave'a") oraz dr Danuta Mucha („Inni jako bohaterowie powieści Tomasza Manna «Czarodziejska Góra»").

Pedagog wobec Inności to temat przewodni sekcji V, którą prowadziła dr Katarzyna Pawelczak. Prelegenci w swoich wystąpieniach przedstawili zadania stojące przed pedagogami specjalnymi. Zwrócili również uwagę między innymi na: zagadnienia dotyczące dzieci ze specjalnymi potrzebami edukacyjnymi, problem powszechności fobii szkolnej, funkcjonowanie uczniów z zespołem Aspergera oraz 6-latki z wadą słuchu wobec obniżonego progu szkolnego.

Mgr Joanna Doroszuk zaprezentowała niezwykle ciekawe strategie wspierania rozwoju kompetencji komunikacyjnych. Przybliżyła ona pozostałym referentom i słuchaczom metodę PECS - jej założenia oraz sposób wykorzystywania w efektywnej pracy z dzieckiem niemówiącym.

Podczas ostatniej IV sekcji pod przewodnictwem dr Anety Wojciechowskiej refleksje prelegentów skupiały się wokół tematu: „Rozwiązania 
- modele - wyzwania". Poruszano zagadnienia związane z diagnozą, terapią oraz formami pracy z "Innym”, na przykład wspieranie ucznia dwukulturowego, bajka edukacyjna, animaloterapia.

Pod znakiem, zapisanych w temacie, wyzwań odnaleźć można zagadnienia łączące się z polskim prawem. Dr Teresa Serafin $\mathrm{w}$ zaprezentowanym referacie podjęła ważny i trudny temat, jakim jest prawo oświatowe w kształceniu specjalnym. Dr Katarzyna Jadach przedstawiła "Innego” jako każdego z nas. Stwierdziła, że w obliczu znajomości prawa, umiejętności odczytywania i analizowania przepisów potrzebujemy wsparcia, pomocy i nakierowania.

Zarówno referenci, jak i słuchacze zaangażowani byli we wszystkie wystąpienia, wzbogacając je przytaczanymi własnymi doświadczeniami, uwagami oraz refleksjami.

Następnie prelegenci wraz z pozostałymi uczestnikami konferencji spotkali się na ostatniej - III sesji plenarnej. Odbyła się ona pod przewodnictwem dr hab. prof. UWM Agnieszki Żyty i dr hab. Urszuli Bartnikowskiej. Referaty, oparte zarówno na badaniach empirycznych, jak i osobistych doświadczeniach oraz własnych refleksjach zaprezentowało grono znakomitych naukowców.

Prof. dr hab. Aniela Korzon („Inny w przestrzeni edukacyjnej i społecznej a bariery - nie tylko architektoniczne") przedstawiła utrudnienia natury społeczno-egzystencjalnej stojące na drodze zarówno dziecka, jak i dorosłej osoby z niepełnosprawnością.

Tematykę „Innej” dorosłości osób z niepełnosprawnością poruszyli: dr hab. prof. UW Grażyna Dryżałowska („Osoba niepełnosprawna - Inny dorosły"), a także Doc. PhDr. Jaroslav Balvin („Jinakost v andragogice”), który rozpatrywał pojęcia związane $\mathrm{z}$ odmiennością $\mathrm{w}$ andragogice, ukazując sytuację "Innych” dorosłych w Czechach.

Natomiast dr hab. prof. WSNS Hanna Żuraw wystąpiła z referatem pt. „Produkcja i żywot inności w społeczeństwie ryzyka. Inny w przestrzeniach życia społecznego".

Dr hab. prof. UG Sławomira Sadowska zwróciła uwagę na kwestię wpływu kultury szkolnej na proces tworzenia edukacji („Praktyka tworzenia edukacyjnej wspólnoty - o edukacyjnej codzienności w kontekście jawnych i ukrytych wzorów kultury szkolnej").

Dr hab. prof. UZ Zdzisława Janiszewska-Nieścioruk w prezentowanym referacie przedstawiła swoje rozważania na temat edukacji integracyjnej. 
Tematykę Innych jako imigrantów poruszyła Doc. PhDr. Jarmila Novotna z MBADubnický technologický inštitút vDubnici and Váhom, Masarykova Univerzita $\mathrm{v}$ Brně, omawiając położenie rodzin romskich, a także dr hab. prof. UAM Eva Zamojska, która rozważała sytuację Innych - Obcych, odwołując się do pozycji społecznej i edukacyjnej imigrantów na gruncie polskim.

Natomiast dr hab. prof. APS Bernadeta Szczupał („Osoby starsze we współczesnym systemie ochrony zdrowia") swoje rozważania osadziła w kontekście polskiego systemu opieki zdrowotnej. Zwróciła uwagę na kwestie dotyczące sposobu traktowania, podejścia personelu medycznego oraz możliwości uzyskania odpowiedniej i satysfakcjonującej pomocy medycznej przez starszych pacjentów.

Kwestię miejsca zajmowanego w społeczeństwie przez osoby z zaburzoną sprawnością komunikacyjną omówiła dr hab. prof. UP Grażyna Gunia.

Wyniki badań własnych w referacie pt. „Inne, czy takie same? Społeczna perspektywa postrzegania kobiet z zespołem Turnera" zaprezentowały dr hab. Anna Jakoniuk-Diallo i dr Hanna Kubiak.

Kolejna prelegentka dr hab. prof. URz Krystyna Barłóg („Trajektoria cierpienia rodziców dzieci niepełnosprawnych: sens życia, szczęścia, a sens cierpienia") zagłębiła się w rozważania aksjologiczne dotyczące cierpienia, ujmując je jako czynnik mogący mieć pozytywny wpływ na funkcjonowanie rodziny dziecka $z$ niepełnosprawnością.

Wystąpienie zamykające obrady należało do prof. dr hab. Marzeny Zaorskiej, która zarysowała drogę rozwoju pedagogiki specjalnej. Ukazała, jak może ona wyglądać w XXII w.

Oficjalnego zakończenia konferencji dokonała prof. zw. dr hab. Iwona Chrzanowska, która podziękowała prelegentom oraz słuchaczom za liczne obrady, spotkania i rozmowy, podczas których znakomici polscy i zagraniczni przedstawiciele nauk pedagogicznych i gałęzi pokrewnych po raz kolejny pochylili się nad Innym. Dzięki temu możliwe było podjęcie próby wypracowania nowego spojrzenia na Innego oraz zrozumienia, czym $\mathrm{w}$ istocie jest spotkanie $\mathrm{z}$ Nim $\mathrm{w}$ przestrzeni społecznej. Wyraziła również nadzieję, iż temat Innego rozpatrywany będzie jeszcze wielokrotnie. 